\title{
Commodore Sir Edward W. C. R. Owen: Shaping the British Naval Establishment on the Great Lakes in the Wake of the War of 1812
}

\section{Thomas Malcomson}

\begin{abstract}
À la fin de 1814, le commodore Sir Edward W.C.R. Owen a été envoyé dans la région des Grands Lacs afin de continuer la guerre contre les Américains. Au lieu de cela, il s'est vu chargé de réduire les forces sur les lacs au lendemain de la guerre et d'établir la paix dans les mers intérieures. Au cours de l'année qu'il a passée au Canada, Sir Edward a aidé à retirer les troupes de la province du Haut-Canada, à résoudre les problèmes d'équipage des navires restés en service et à rédiger des rapports pour l'Amirauté sur les améliorations à apporter aux communications et à la défense le long des Grands Lacs.
\end{abstract}

At the end of 1814, Commodore Edward Owen was sent to North America to wage war against the Americans on the inland seas. Instead, he oversaw the shift from a war footing to a peace establishment. ${ }^{1}$ He made a signal contribution in securing the tenuous new peace between Britain and the United States by rapidly reducing forces, while also reorganizing the naval establishments and placing ships, bound for ordinary, in a state of readiness that would enable a quick return to service if the delicate peace collapsed. These were enormous tasks in a vast and complex theatre during a time of continued border tensions, and yet have not been treated in either biographies of Owen or studies of peacemaking and defence preparations in the wake of the War of $1812 .^{2}$ This paper will examine the role

1 The author wishes to thank Roger Sarty and Richard Gimblett for wading through an earlier draft of the manuscript. Their suggestions were essential for the revisions. Any fault rests with the author.

2 Mentioned in passing in J MacKay Hitsman. Safeguarding Canada 1763-1871 (Toronto, ON:

The Northern Mariner / Le marin du nord, XXIX, No. 1 (Spring 2019), 1-24 
The Northern Mariner / Le marin du nord

Owen played in the shift from war to peace on the Great Lakes, in 1815.

\section{Sir Edward's Early Career}

Edward William Campbell Rich Owen, the first illegitimate son of Welsh born Royal Navy Captain William Owen, came into the world on 19 February 1771, at Campobello, Nova Scotia. ${ }^{3}$ Captain Owen returned to England and managed to have his son's name placed in Sir Thomas Rich's ship's muster, as a servant, in 1774. ${ }^{4}$ Edward's navy experience began in earnest in 1780, and followed much the same path as other contemporary officers. After the required time as a midshipman, followed by a lieutenancy he became a captain in 1798 , with the requisite patronage of senior officers. ${ }^{5}$ Edward Owen's experience on the French and Dutch coasts during the French Revolutionary and Napoleonic Wars, honed his skills in cutting out expeditions, coastal bombardment, and trade interdiction. He participated in the doomed Walcheren expedition in 1809, earning accolades for his work in the frigate Clyde. ${ }^{6}$ More inshore activity followed until he was moved into the Dorset yacht in July 1814, at Deptford. On 12 December he received orders to take command on the inland seas of the North American Station. In April 1815, among the many honours awarded for service during the Napoleonic War, Owen was created a Knight Commander of the Bath. ${ }^{7}$

University of Toronto, 1968), 110-129; C. P. Stacey, "The Myth of the Unguarded Frontier 18151871" The American Historical Review 56:1 (October 1950), 1-18; A. L. Burt, The United States Great Britain and British North America: From the Revolution to the Establishment of Peace after the War of 1812 (New Haven, CT: Yale University Press, 1940); and Kenneth Bourne, Britain and the Balance of power in North America 1815-1908 (Los Angeles, CA: University of California Press, 1967). There is no mention of Sir Edward Owen in R.A. Preston “The Fate of Kingston's Warships" in M. Zaslow (ed.). The Defended Border: Upper Canada and the War of 1812 (Toronto, ON: Macmillan Company, 1964), 283-95. Owen is not mentioned and there is very little coverage of the dismantling of the war effort in 1815 in Gerald S. Graham's work Sea Power and British North America 1783-1820 (Cambridge MA: Harvard University Press, 1941). In terms of his biography see, William O'Byrne, A Naval Biographical Dictionary, Vol. 2, (London, UK: 1849), 845-846; John Marshall (ed.), Royal Naval Biography Vol. 2, (London, UK, 1824), 126-135; "Owen, Sir Edward William Campbell Rich (1771-1849) of Deal, Kent" History of Parliament Online at http://www. historyofparliamentonline.org/volume/1820-1832/member/owen-sir-edward-1771-1849 [History of Parliament]; "Obituary, Adm. Sir E. W. C. R. Owen, G.C.B” Gentleman's Magazine 182 (December 1849), 647. While there is an entry for his half-brother William Fitzwilliam Owen, Sir Edward does not have an entry in the Canadian Dictionary of Biography. There is no mention of his time on the Great Lakes in the biographical entry in the Oxford Dictionary of National Biography, v 42, (Oxford, UK: Oxford University Press, 2004), 195.

3 With the creation of New Brunswick in 1784, the island was transferred to that jurisdiction.

4 See "Owen" entry, History of Parliament, para. 1. Unless otherwise noted, Sir Edward W. C. R. Owen's naval career summary is taken from O’Byrne. The ship was HMS Enterprise.

5 His patrons included Rear Admiral Sir Thomas Rich, and Vice Admiral John Colpoys.

6 G. C. Bond, The Grand Expedition: The British Invasion of Holland in 1809 (Athens: University of George Press, 1979), 45-50, \& 139.

7 "New Regulations respecting the Order of the Bath." The Scots Magazine and Edinburgh Literary 77 (April 1815), 263-8, see 266. 


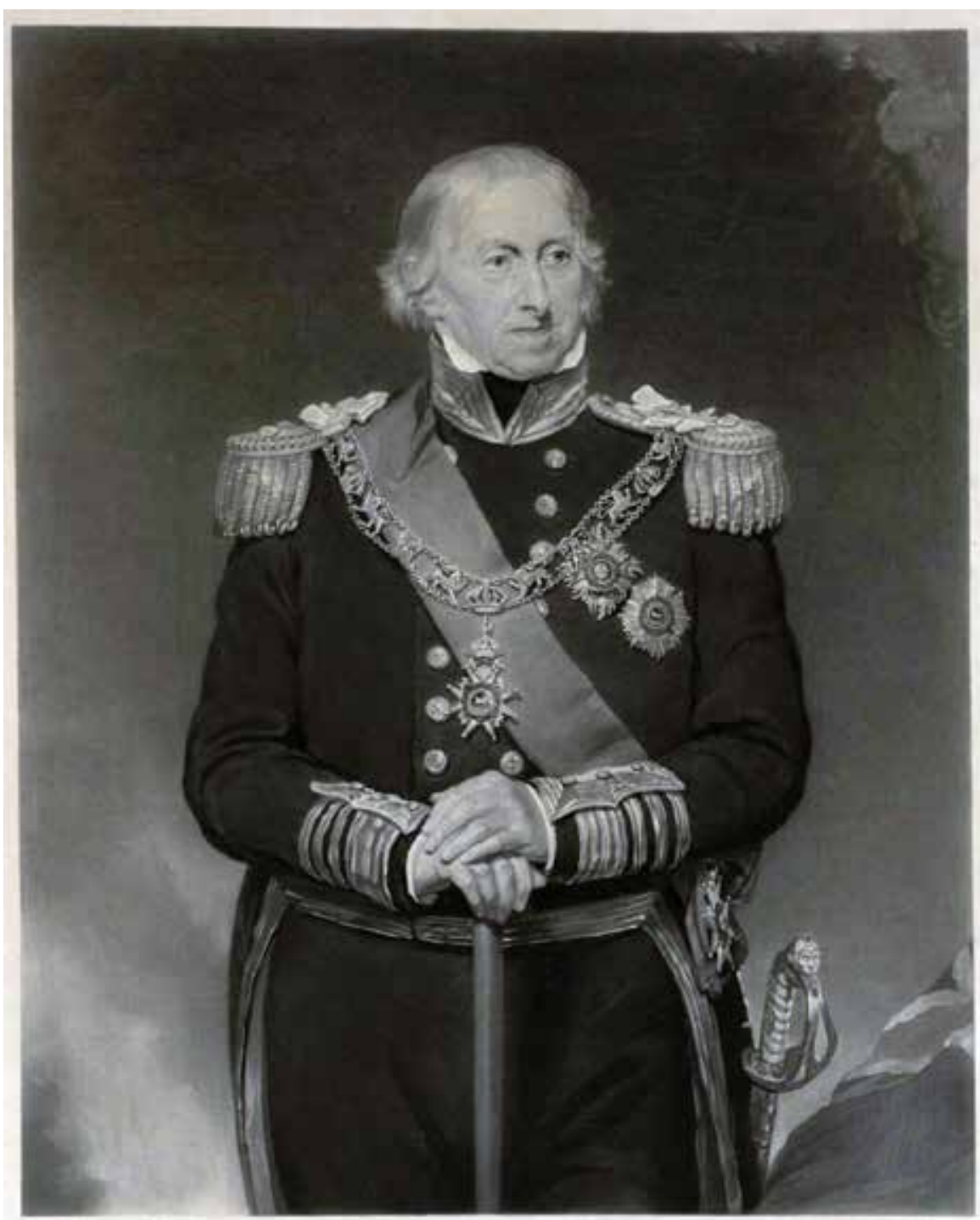

Admiral Sir Edward W. C. R. Owen, from a portrait by H. W. Pickersgill, c 1849

\section{Assignment to Canada and the Change in Task}

Commodore Owen boarded HMS Niobe on 17 December 1814 for the trip across the Atlantic to Halifax. Midshipman Alexander Thomas Emeric Vidal joined him as secretary. ${ }^{8}$ They travelled with Major General Sir George Murray,

8 Details of the crossing and trip to Kingston come from: "Commodore Owens, Lakes" 17 December 1814 to 31 January 1815, National Archives of the United Kingdom [NAUK], ADM 50/111, 209-22; "Passengers on the Niobe" Quebec Gazette 2612 (2 March 1815), 2; "Arrived in Quebec", Quebec Gazette 2613 (9 March 1815), 2; \& "Montreal March 11" Quebec Gazette 2614 
who was to give Governor-in-Chief of North America Sir George Prevost the letter recalling him to London, replacing him with Sir Gordon Drummond, then military commander and lieutenant governor of Upper Canada. The ship also gave passage for several junior military and naval officers, 150 soldiers of the Royal Artillery and 140 seamen for the ships on the North American Station. After an uneventful crossing the Niobe arrived in Halifax, on 29 January 1815. Owen, Vidal, and Murray landed at Quebec City on 26 February and stayed through 8 March. News of the ratification of the Treaty of Ghent and the cessation of hostilities arrived 1 March. ${ }^{9}$ Prevost immediately ordered Drummond to reduce costs in all public departments, halting work on all fortifications, except the citadel at Kingston. ${ }^{10}$ Troop reduction in the right and centre divisions would occur as soon as transports were available.

While in Quebec Owen evaluated an Admiralty idea of securing large ships there, and sending their men and guns into the lakes. ${ }^{11}$ With the assistance of the Harbour Master J. Hambly, he found such a spot. He also suggested some of the rivers feeding into the St Lawrence further upstream, in particular at Trois Rivières. Taking the steam boat from Quebec, he and Vidal arrived in Montreal 9 March, reaching Kingston on 19 March, by the less then comfortable passage in a bateau. ${ }^{12}$ With the numerous rapids at the lower end of the St Lawrence River, the party had experienced the ten portages between Montreal and Cornwall. The foot paths and mud roads were nearly impassible, showing Owen first hand, how difficult transportation was into the upper province. On arriving at Kingston, Commodore Owen entered the frigate HMS Psyche and took command of the Great Lakes on 22 March. Sir James Yeo hauled down his pennant and made arrangements to cross over to Sackets Harbour (at the invitation of American Commodore Isaac Chauncey) and head back to England, via New York City. ${ }^{13}$ Owen then shifted his broad pennant to the first rate, HMS St Lawrence.

His orders on 12 December 1814, had sent Owen out to replace Sir James, who had been the commodore on the inland seas since May 1813. The war on the lakes was in a stalemate, with both sides spending much of 1814 building bigger ships on Lake Ontario. ${ }^{14}$ Lake Champlain had been lost to the Americans in the Battle of

(16 March 1815), 2; Owen to Corker, 4 March1815, Library and Archive of Canada [LAC], ADM 1/2262, mfr B2635. Vidal had served in HMS Cornwall, under Edward Owen, see O'Byrne, 1229. Owen appears to be Vidal's patron.

9 Baker to Prevost, 17 February 1815, LAC, British Military and Naval Records RG 8, C Series, v. 687, mfr. C3231, 131. The British Prince Regent signed the Treaty of Ghent on 30 December 1814, while American government ratified the Treaty on 16 February 1815.

10 Prevost to Drummond, 1 March 1815, LAC, RG 8, v. 1226, mfr. C3527, 25-6.

11 Owen to Croker, 4 March 1815, LAC, ADM 1/2738, 52-3b.

12 Owen to Croker, 25 March 1815, LAC, ADM 1/2262, 110-12.

13 Owen to Croker, 4 March 1815, LAC, ADM 1/2262, 68-9; Yeo to Croker, 23 March 1815, LAC, In-letters, ADM 1/2738, 81.

14 See Robert Malcomson. Lords of the Lake: The Naval War on Lake Ontario 1812-1814 (Toronto, ON: Robin Brass Studio, 1998), Part IV, 225-55. Sir James Yeo had spent much of 1814 building larger ships to dominate over the Americans on Lake Ontario. In April, the large frigates 
Plattsburgh, on 11 September 1814. Lake Erie had been dominated since the fall of 1813 by the Americans, as a result of the British defeat at the Battle of Lake Erie. Having lost their entire squadron, the British had one armed transport vessel on Lake Huron, which they subsequently burnt to avoid its capture. But much of the American forward momentum on the upper lakes had been countered by the British in 1814.

In August 1814 the Americans lost Somers and Ohio to a cutting out raid at Fort Erie. A month later, another cutting out expedition, on Lake Huron, relieved the Americans of Tigress and Scorpion, which were renamed Confiance and Surprise, respectively. ${ }^{15}$ Thus, at the end of 1814 the British had a small but definite presence on the upper lakes. The British sank the Somers and Ohio at the mouth of the Chippawa River, to prevent their re-capture. Once the British could establish a new naval base on Lake Erie, the two schooners would be raised and employed.

The new year promised to be the deciding one, thus determining the fate of the upper province. By the time Owen arrived at Quebec, however, the war was over, and his mission changed. Now he would lead the winding down of the British naval presence on the Great Lakes, and set up a peace establishment, that could be brought back to an adequate war footing, if needed, to challenge a possible American renewal of war. ${ }^{16}$ The fiscal pressure both countries faced necessitated a downsizing, but continued tensions required a readiness for war.

As 1815 began the Americans were building two 118 gun ships at Sackets Harbor on Lake Ontario. ${ }^{17}$ They were also setting up frames for two frigates and a steam boat. These building endeavours created quite the stir in Kingston. American troops were being moved along the St Lawrence to Ogdensburg, in preparation to cut British communication lines. ${ }^{18}$ Lt.-Gen. Sir Gordon Drummond, in command of Upper Canada, moved forces to counteract this threat, but it was clear the United States would no longer allow the nearly free passage along the only water route

Prince Regent (58 guns) and Princess Charlotte (40 guns) were launched, and building began on HMS St Lawrence, 104 guns. The Americans built the 58 gun frigate Superior in response to the British frigates, and had laid down the keels of two 118 gun first rate ships.

15 R. Malcomson, Lords of the Lake, 296; J. Mackay Hitsman. The Incredible War of 1812: A Military History (1965), (Toronto, ON: Robin Brass Studio, updated 1999), 236; Barry Gough, Fighting Sail on Lake Huron and Georgian Bay: The War of 1812 and its Aftermath (St Catharines, ON: Vanwell, 2002), 107-116.

16 Bourne, 14-15.

17 Sherbrooke to Bathurst, 17 January 1815, LAC, RG 8, v. 687, mfr. C3231, 42-4; Drummond to Prevost, 11 February 1815, LAC, RG 8, v. 687, mfr. C3231, 104-7; Drummond to Prevost, 14 February 1815, LAC, RG 8, v. 687, mfr. C3231, 108-13. The two ships were named Chippawa and New Orleans.

18 The Americans planned to invade Upper Canada in 1815, along the St Lawrence with a force large enough to beat any British counter attack. The goal was to drive the British into Lower Canada, preferably to Quebec City. This would give the Americans the upper province, and necessitate the reassignment of British forces from the east coast of America to Lower Canada and Nova Scotia. See C. Stacey, "An American Plan for a Canadian Campaign” in M Zaslow (ed.), The Defended Boarder: Upper Canada and the War of 1812 (Toronto, ON: Macmillan Company, 1964), 273-82. 
into the upper province, as it had in the previous two years. On Lake Erie, a large barracks was built at Buffalo, with fifty chimneys. General Jacob Brown was said to be moving 2,500 troops to the Detroit area. A Mrs McIntosh, who travelled from Sandwich, near Detroit, to Dundas, just west of Burlington, told of an American plan to raid the village of Delaware, along the Thames River. ${ }^{19}$ It appeared that the year would start with multiple attacks by the Americans.

One of Yeo's ideas, expressed to Prevost in January 1815 was to construct three frigates and two large brigs at Isle aux Noix, the key British defensive establishment on the Richelieu River south of Montreal that guarded the approach to Canada, to divert American attention and shipwrights from Lake Ontario, thus stalling their ship building at Sackets Habor. ${ }^{20} \mathrm{He}$ was convinced such a force could recapture Lake Champlain. Yeo wanted to continue building the two first rate ships on the stocks at Kingston, to offset the American building at Sackets, which he considered closer to launch than the British ships. At the beginning of January 1815 he told John Wilson Croker, first secretary of the Admiralty that he had requested all the ordnance stores at Quebec for the two new ships, and about the proposed building at Isle aux Noix. Yeo also requested guns to complete the armaments of Psyche and Princess Charlotte. He suggested that the needed cannons be taken from the forts and batteries at Quebec, if necessary.

In January, Yeo visited Turkey Point on Lake Erie to see if it was a good spot for a naval establishment. ${ }^{21}$ He then attempted to go to Penetanguishene, on Lake Huron's Georgian Bay, but only made it as far as Lake Simcoe due to the weather, before returning to Kingston in mid February. Commodore Yeo had sent Captain Edward Collier to Penetanguishene, at the end of 1814 , to prepare the site for a proposed naval establishment on the upper lake, and to set about building a frigate..$^{22}$ The stores for such a venture were in transit to Lake Simcoe.

On February 25, 1815 Sir James received a message from American Commodore Isaac Chauncey, at Sackets Harbor, indicating the ratification of the Treaty of Ghent, a copy of which was attached. ${ }^{23}$ Yeo asked Prevost if all building should stop. If not, he could send artificers to Lake Erie to start on the base at Turkey Point. He repeated that finishing the first rate ships at Kingston was absolutely necessary, even if peace continued.

19 Drummond to Prevost, 16 February 1815, LAC, RG 8, v. 687, mfr. C3231, 114-19. Delaware is 10 kilometres west of London, Ontario.

20 Yeo to Prevost, 6 January 1815, LAC, State Papers Lower Canada Sir George Prevost - 1815, Q131, mfr C11922, 5; Yeo to Croker, 1 January 1815, LAC, ADM 1/2738, 22-23b.

21 Drummond to Prevost, 14 February 1815, LAC, RG 8, v. 687, mfr. C3231, 108-13.

22 Yeo to Croker, 24 October 1814, LAC, ADM 1/2737, 221-26. Yeo to Prevost, 22 November 1814, LAC, RG 8, v. 733, mfr. C3244, 123-28.

23 Yeo to Prevost, 25 February 1815, LAC, ADM 1/2262, 71-b. Yeo to Prevost, 25 February 1815, LAC, RG 8, v. 687, mfr. C3231, p142-4; Gough, 129. 


\section{Under Owen's Direction}

Owen saw and thoroughly agreed with Yeo's letter to Prevost, regarding what to do on the lakes. ${ }^{24}$ Besides the measures to secure lake Ontario Sir James urged the re-establishment of a naval presence on Lake Erie, as quickly as possible. Commodore Owen wrote Croker at the Admiralty informing him that all the ships were in some state of being dismantled, except HMS Psyche, which still needed some gun carriages. The brig HMS Niagara had wintered at York, allowing Collier with some of his crew and a party of artificers, to proceed to Penetanguishene. He told the Admiralty that he would use the two schooners on Lake Huron to supply the British at Mackinac Island, which they had captured from the Americans in 1812. Owen ordered Captain Edward Collier to proceed to Fort George and raise the two schooners captured at Fort Erie, and sunk at the mouth of the Chippawa. They would serve as transports for the army on Lake Erie. The schooners were named Sauk (former Ohio) and Huron (former Somers) and Owen sent officers and eighteen men for each one. ${ }^{25}$

Sauk and Huron proved not to be effective, however, so Owen ordered two transports to be built for Lake Erie, to be named Newash and Tecumseth. ${ }^{26}$ They would each be fitted for two long guns and two carronades, but would go unarmed in peacetime. After Drummond approved of the project, Owen sent Kingston Dockyard Commissioner Sir Robert Hall and a party of shipwrights to build the vessels, a mile up the Chippawa River from the Niagara River, at Street's Farm. The frames and planks were taken from the trees along the Chippawa and Niagara Rivers. All other stores for the ships, including rigging and sails came from Kingston's naval supplies.

Owen had written Hall, from Quebec, about his intentions for construction, after seeing Yeo's letter and discussing its contents with Prevost. ${ }^{27} \mathrm{He}$ wanted the two first rates to be brought forward to a state ready for launching, but kept on the stocks to season. Fearing the rumoured advanced state of the two American first rates, Owen urged Hall to work quickly, to regain the lead. All other expenses were to be curtailed, except where work was needed to keep ships ready to re-engage in war. Commissioner Hall had released the parties of contracted shipwrights for one of the two first rate ships and sent them away upon hearing the news of peace.

24 Owen to Corker, 4 March 4 1815, LAC, In-letters, ADM 1/2262, 67-8. This letter contains the letter noted from Yeo detailing American ship building at Sackets Harbour. Yeo to Croker, 20 January 1815, LAC, ADM 1/2738, 46-7; Yeo to Croker, 25 February 1815, LAC, ADM 1/2738, 78-9.

25 Owen to Hall, 16 April 1815, LAC, ADM 1/2262, 159-9b. Hall to Myers, 21 May 1815, LAC, RG 8, v. 695, mfr. C3234, p76-7. The schooners cost $£ 950$, in total. Owen to Drummond, 13 June 1815, LAC, RG 8, v. 735, mfr. C3244, 23-8.

26 Owen to Drummond, 4 April 1815, LAC, RG 8, V. 734, mfr. C3244, 66-8; Foster to Murray, 8 April 1815, LAC, Military Secretary Letter Book, Foster, [MSLB-Fo], RG 8, v. 1235, mfr. C3528, 5-6. Owen to Drummond, 14 April 1815, LAC, RG 8, v. 370, mfr. C2932, 11-17. See, Leeanne E. Gordon, "Newash and Tecumseth: Analysis of Two Post-War of 1812 Vessels on the Great Lakes" (master's thesis, Texas A\&M University, 2009).

27 Owen to Hall, 10 March 1815, LAC, ADM 1/2262, mfr. B2635, 75-6. 
The Admiralty was not happy to hear this news. Hall also had cancelled an order for iron work for one of the ships, from a local iron mill, so all iron work would have to come from England. ${ }^{28}$ Owen approved Yeo's plan to construct a frigate at Penetanguishene, and thought it could hold the upper lakes, until he could get a better grasp of the British needs.

The other building project was at Isle aux Noix, where work was beginning on one of the three frigates that Yeo had proposed. Owen discontinued this project and turned the shipwrights over to building a dozen gunboats. ${ }^{29} \mathrm{He}$ travelled to the island to see for himself the ongoing work and the needs of the establishment. ${ }^{30}$ Afterward, additional shipwrights and sail makers were sent to finish the gunboats. ${ }^{31}$ The gunboats were laid down during the winter and ready to receive their cannons by May. Owen asked Drummond to forward thirty-two long 24 pounders and four 68 pounder carronades, along with all the stores they required. He was told to acquire the ordnance from the Admiralty. The shipment of ordnance arrived at Quebec in July, and were forwarded immediately to Isle aux Noix. ${ }^{32}$

With three different designs of gun boats, Owen ordered one of each be put into service and the others kept on shore, ready for use, but covered for protection. He also asked for the boom that had been placed across the river, to keep the American vessels away from Isle aux Noix, be removed and stored safely for re-installation in the event of renewed hostilities.

Another project left over from the war were the frames of a frigate and two brigs sent out from England, in 1814, for use on the lakes, idly sitting in valuable storehouse space at Montreal. ${ }^{33}$ One set of frigate frames and iron work was moved forward, during the summer of 1814, to Kingston, becoming HMS Psyche. The question now was, what to do with the others? Owen's first idea was to bring them to Kingston and set them up, but not plank them. ${ }^{34}$ He changed this to perhaps using them at Isle aux Noix, but confronted with the price of either endeavour he chose to order their sale. In the end, the frames of the two brigs were set up at Montreal and then sent to Halifax, while the frigate material was sold.

Captain Francis Spilsbury passed through Sackets Harbor on his return to Upper

28 Owen to Croker, 4 March 1815, LAC, ADM 1/2262, mfr. B2635, 68.

29 Owen to Croker, 25 March 1815, LAC,ADM 1/2262, mfr. B2635, 110-11; Owen to Drummond, 10 May 1815, LAC, RG 8, v. 734, mfr. C3244, 119-21.

30 Owen to Drummond, 10 May 1815, LAC, RG 8, v. 734, mfr. C3244, 119-21.

31 Baumgardt to Owen, 3 July 1815, Queens University Archive [QAB1]; Owen to Laws, 10 July 1815, QAB1.

32 Owen to Drummond, 10 July 1815, LAC, RG 8, v. 735, mfr. C3244, 54.

33 Thomas Malcomson, "HMS Psyche: Frigate in Frame" Seaways' Ships in Scale 4:6 (Nov/Dec 1993), 16-21.

34 Owen to Croker, 2 April 1815, LAC, ADM 1/2262, mfr. B2635, 126-50; Hall to Owen, 2 July 1815, LAC, ADM 1/2263, mfr. B2634; Hall to Owen, 2 July 1815, LAC, ADM 1/2263, mfr. B2635, 13; Hall to Owen, 3 July 1815. LAC, ADM 1/2263, mfr. B2635, 14; Owen to Laws, 17 July 1815. QAB1; \& Owen to Dobbs, 17 July 1815. QAB1. The two brigs were named Colibre and Goshawk, the frigate was to be named Prompte. 
Canada, after being released as a prisoner of war. ${ }^{35}$ He noted that the Americans were withdrawing forces from Sackets, reducing the naval force to only the Jones. Even the Jones was switching out her heavy carronades for the Sylph's lighter guns. Owen passed this intelligence along to Croker adding he had no information about Lake Erie. On Lake Champlain he heard that the Americans would only keep the Linnet active, all the others to be laid up. On 27 February 1814 President Madison had ordered the laying up of all vessels of war, on the Great Lakes, not required for the revenue service. ${ }^{36}$

In April Sir Gordon Drummond had suggested that the transport vessel owned by the army could be purchased into the navy's service. ${ }^{37}$ Owen informed Drummond that HMS Montreal had been given a spar deck, had its ports closed, and was now a transport vessel. He suggested that the squadron could provide enough transport space, that no additional shipping was necessary. Sir Gordon responded by laying up all the commissariat's vessels, except a gunboat, to be used as an express between York and Kingston and requested Owen supply the crew. ${ }^{38}$

In June Sir Edward, as by now Owen become, had the Prince Regent land its guns and serve as a troop ship for carrying the army from York and Niagara, to Kingston. The Montreal was so leaky that he regarded it unusable, until he had a report from the builder as to what might be done to fix the situation. The Princess Charlotte was so short of complement it could not sail. He was informed that the St Lawrence's gun carriages on the lower deck were too short for the guns they carried, and needed to be replaced. ${ }^{39}$

Sir Edward found the dock yard and anchorage to be too crowded for the new ships building. In late March, he instructed John Harris, Master of HMS St Lawrence to survey the harbour once the ice broke up. Owen wanted to find places to put the ships but still have them protected by the fortress at Point Frederick, and the citadel on Point Henry.

\section{Transporting troops and seamen out of North America}

With the American War over, and Europe relatively calm for the first time in over two decades, Britain desperately needed to cut its expenses. Lord Bathurst, Secretary of War and Colonies, ordered Drummond to not delay in sending home soldiers and sailors serving in Canada. ${ }^{40}$ For those serving in western Upper Canada, the first leg of their trip home was via the Lake Ontario squadron, from Niagara to Kingston, where they transferred to smaller craft for the ride down the St Lawrence to Montreal. From Montreal the transportation service, for which Owen was

35 Owen to Croker, 2 April 1815, LAC, ADM 1/2262, mfr. B2635, 126-50.

36 Burt, 388.

37 Owen to Drummond, 6 April 1815, LAC, RG 8, v. 734, mfr. C3244, 69-71.

38 Drummond to Owen, 18 April 1815, LAC, MSLB-Fo, RG 8, v. 1228, mfr. C3527, pp, 19-20.

39 Fisher to Owen (extract), 24 June 1815 and Owen to Drummond, 25 June 1815, LAC RG 8,v. 735, mfr. C3244, 33; \& 34-6.

40 Bathurst to Drummond, 20 March 1815, LAC, RG 8, v. 678, mfr. C3231, 196-7. 


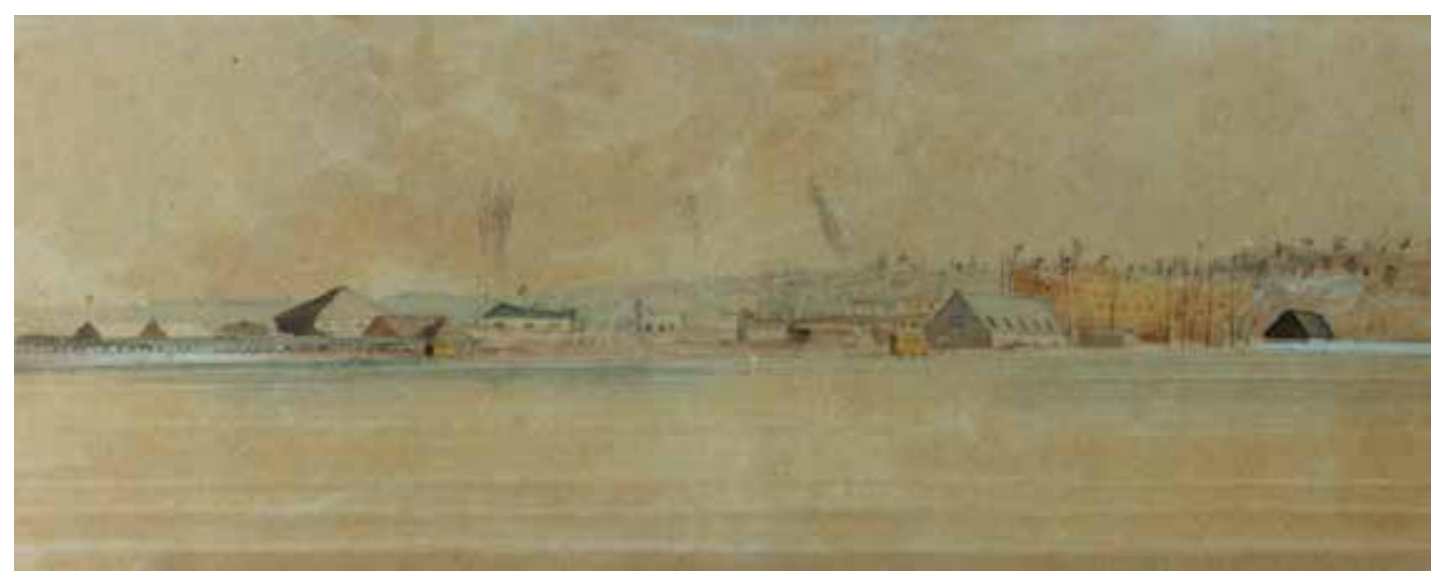

Lt. A. Vidal, “Kingston Harbour, Lake Ontario, taken July 1815” (Courtesy Royal Military College)

responsible, moved the departing forces to Quebec. At Quebec, Owen had placed Captain Alexander Dobbs as acting transport agent. Dobbs was responsible for boarding and keeping track of the troops sent into transports headed for England. For general and staff officers, Owen was required to issue their passes to board transports for England. ${ }^{41}$

In April the task of moving troops from the Niagara peninsula began. As noted above, the Prince Regent was now serving as a troop transport. ${ }^{42}$ Owen sent 250 marines to Cornwall to help with the movement of the army and its material out of the province. Gunboats carried troops from Kingston to Prescott. On the back of the letter describing this activity an Admiralty minute noted that he was not charged with transporting the army. By the time this admonishment reached Owen the activity was completed.

In early June the Lake Ontario squadron were sent to carry the 6th and part of the 82nd Regiments from Niagara back to Kingston. ${ }^{43}$ Before retrieving the troops going home, the Glengarry Light Infantry were to be carried to York, from which the Canadian Fencibles were to be delivered to Niagara. The Prince Regent, Psyche, Montreal and Niagara were sent. On leaving Kingston the Prince Regent ran aground, damaging its keel, and taking three days to get free. The four ships continued on their assignment and returned with the troops.

At the end of May, the twenty-three transports that had wintered at Quebec and the additional thirty, just arrived, prepared to board the 12,000 men, waiting to go home. ${ }^{44}$ By July, Dobbs had another group, of just over 16,000 men, aboard transports, for their return home. ${ }^{45}$ This group included officers, seamen, and marines from the Lakes service, and over 400 seamen who were former prisoner's

41 Foster to Owen, 26 May 1815, LAC, MSLB-Fo, RG 8, v. 1228, mfr. C3527, 98.

42 Owen to Croker, 2 April 1815, LAC, ADM 1/2262, mfr. B2635, 126-50.

43 Davies to E. Owen, 5 June 1815, LAC, ADM 1/2262, mfr. B2635, 263-7.

44 Drummond to Griffith, 26 May 1815, LAC, MSLB-Fo, RG 8, v. 1228, mfr. C3527, 99.

45 Drummond to Bathurst, 10 June 1815, LAC, MSLB-Fo, RG 8, v. 1230, mfr. C3528, 33-4;

Drummond to Bathurst, 1 July 1815, LAC, MSLB-Fo, RG 8, v. 1230, mfr. C3528, 39-40. 


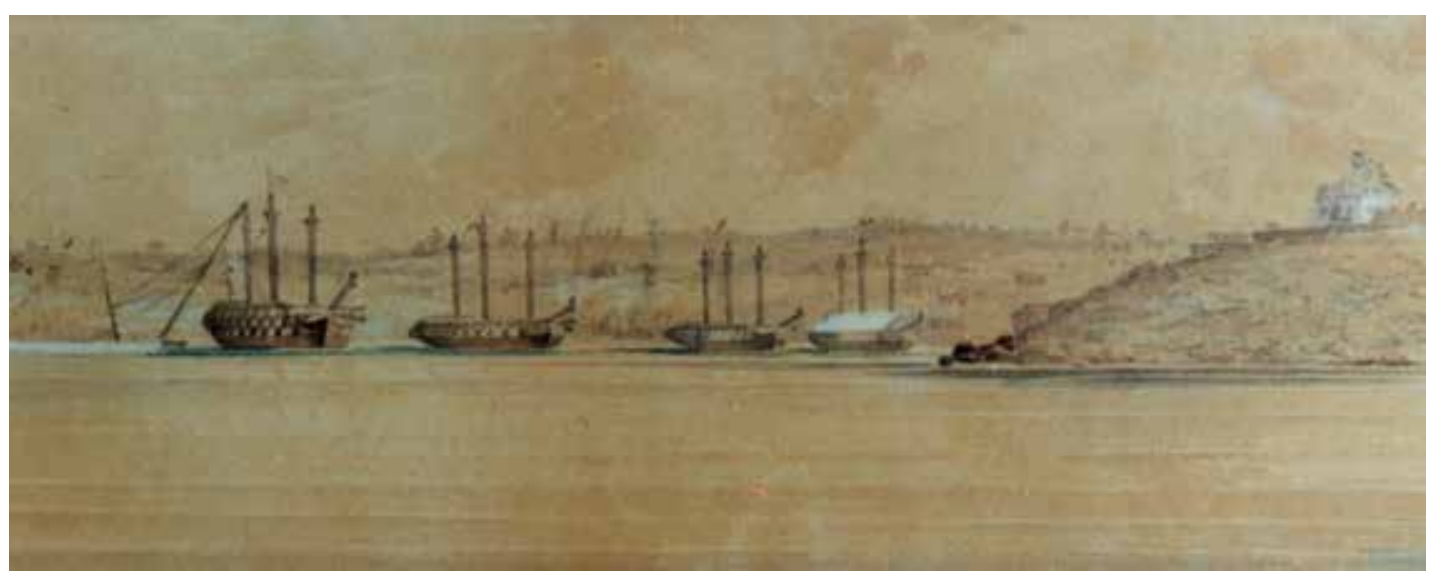

of war. These transports all left Quebec, by mid July. Moving troops out of the upper province was basically complete. Owen would send more seamen and officers home in the fall.

Since his arrival, Owen had inspected Kingston dockyard thoroughly, and consulted with Dockyard Commissioner Captain Hall. He then traveled to Isle aux Noix in early May, after which he journeyed on to Quebec, to discuss the situation on the lakes with Governor-in-Chief Drummond. ${ }^{46}$ While there Owen helped deal with the wreck of HMS Penelope, a ship bound home with dispatches. He welcomed his half-brother Captain William FitzWilliam Owen who arrived from Portsmouth. William was assigned to conduct a survey on the Great Lakes. Sir Edward also wrote the Admiralty to inform them of all he had done. In this letter he described briefly the disruption in transportation from Montreal to Kingston, along the St Lawrence River. The first problem was very close to Montreal, at Sault of St Louis, the next a set for rapids between Pointe-des-Cascades and Coteau-du-Lac, a distance of ten miles, and the third set were the Long Sault Rapids, from Cornwall to almost Fort Wellington, approximately fifty miles, some of which was easily within American control. Each spot where there was a rapid required portage and the dragging of the bateau, barges or freight canoes through the churning waters. Owen mentioned the proposed canal from LaChine through Montreal, which would avoid the rapids and falls at Sault of St Louis. ${ }^{47}$ While there were locks to assist in raising the bateau up the rapids at Pointe-des-Cascades and Coteau-du-lac, Owen felt a canal could be cut through the small peninsula and by pass both rapids at once. He suggested the new locks be made large enough to take the largest vessels used on the river. This would be a bateau nearly sixty feet long and fifteen feet wide.

46 Owen to Croker, 28 May 1815, LAC, ADM 1/2263, mfr. B2635, 119-25b.

47 The Lachine canal was first proposed in 1805, but was not completed until 1826, See Bourne, 36. 
Reporting on Lake Ontario, Owen told Croker that the Americans at Sackets were ready to raise another first rate ship as soon as they launched one of the two currently building. But the artificers had been sent to the east coast and building seemed to have stopped. Sir Edward compared HMS Montreal and Niagara and his smaller vessels to the similar sized American ships and rated the British ones as inferior. In particular, the Americans used more wood, giving their ships "greater strength and their people better shelter." On paper the differences did not appear as readily, as to those who knew the ships and vessels in more detail.

As Lake Ontario was the key to the possession of Upper Canada, he urged retaining a strong force on the lake. He suggested one warship on each lake during peace, and ships in ordinary ready for quick re-entry into service. Owen requested the ordnance, again, for the ships building at Kingston. He also made the Admiralty aware that economy was a guide for his decisions.

\section{Designing The Naval Peace Establishment}

In June, Owen decided on the Naval Peace Establishment for the lakes..$^{48}$ Three gunboats and the sloop HMS Champlain would be the force at Isle aux Noix. Captain William Baumgardt would have a total of 135 men of which sixty-five officers and seamen, would man the sloop. In addition there would be five boys and sixty-five Royal Marines to be divided between the sloop and gunboats. Nine artificers were added. This was a reduction by almost half of all the men entered

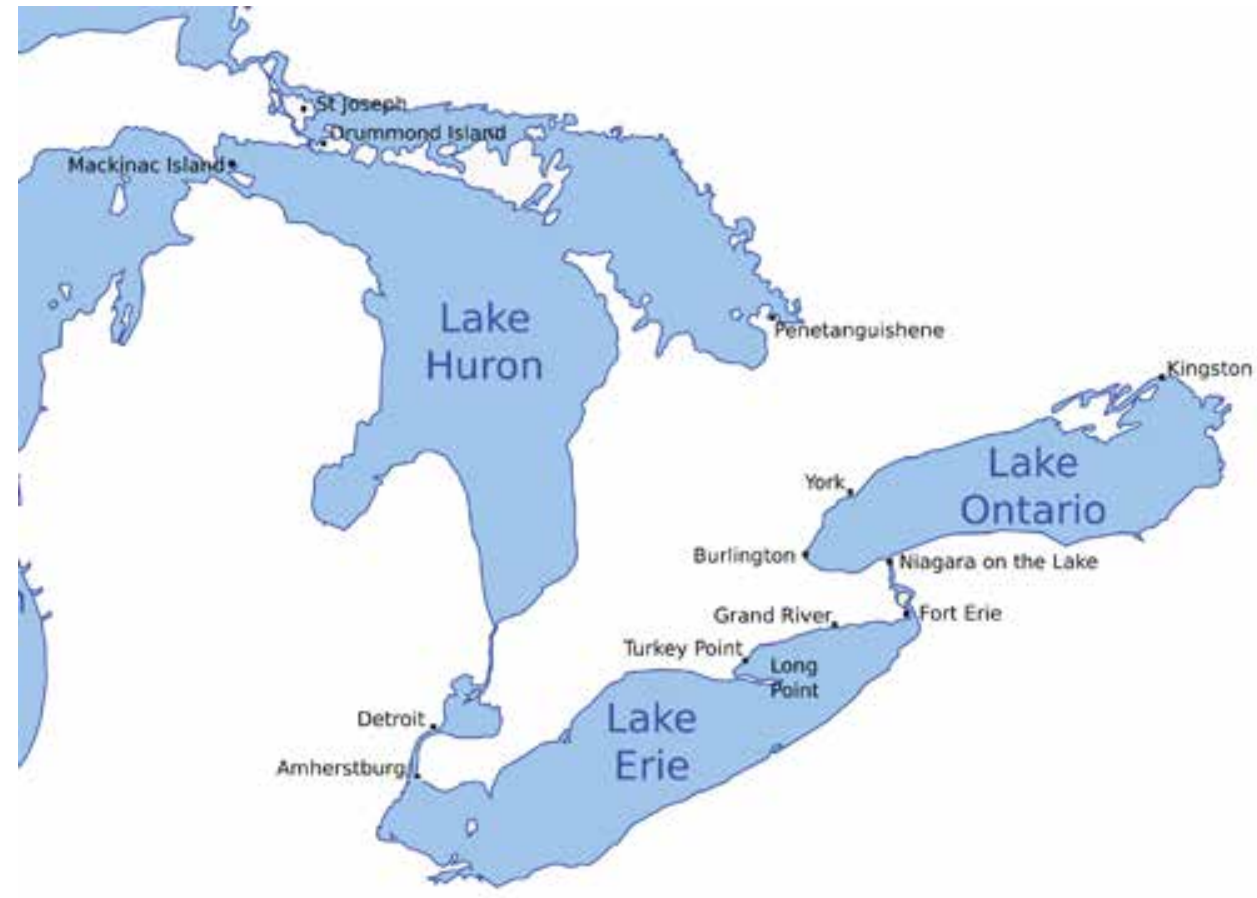

48 Owen to Drummond, 16 June 1815, LAC, RG 8, v. 735, mfr. C2344, 8-17. 
into the muster table between 12 September 1814 and 30 June $1815 .{ }^{49}$ Many of the reduced number had self-selected their departure date, as will be discussed below. For the transport and storehouses at Montreal and Quebec, Owen had reduced the civil establishment as much as possible. On Lake Ontario, the squadron remained busy enough that reductions were not possible at this time. Owen anticipated that October would see a reduction down to about one hundred seamen, marines and artificers.

At Sackets the Americans were having a problem with rising water encroaching on their building site and rumours were that they intended to finish and launch the ships to save them. If they completed their two first rate ships Owen stated it was "incumbent upon us...to do the same." ${ }^{50}$ Of the other ships in the squadron, Psyche, Princess Charlotte and St Lawrence were to be laid up. The Prince Regent needed to have its keel examined after the grounding in May. He would reduce that frigate's crew. Niagara's crew would also be reduced and the vessel kept only because it could enter the Niagara River easily. A spar deck would be given to Niagara to make it suitable for transporting troops and stores, as was the Star. The Charwell, that had served during the war was unfit for service and so served for a short time as a powder magazine. A new Charwell, was launched by the end of the year but was a transport only. The Montreal was not mentioned in the letter describing the new establishment.

For Lake Erie, he had not yet decided. The Sauk and Huron had sailed to Amherstburg. Two transports building on the Chippawa River were to be ready in August. The question was were would the British navy locate its Lake Erie dockyard. Amherstburg had proven too exposed to American attack. There were two candidates for the spot: one, the mouth of the Grand River, the second, the area around Turkey Point and Long Point. The Grand River flowed into Lake Erie about thirty-three miles west of Fort Erie and had a sand bar restricting entry into the deep water basin at the river's mouth. Turkey Point was forty miles further west, with the much more prominent Long Point, jutting out into the lake just a bit more west. This natural feature created a good anchorage in the bay between them. Turkey Point had been put forward by Sir Gordon Drummond during 1814 as the best spot. ${ }^{51}$ Sir James Yeo had visited both after the war, and confirmed his opinion that Turkey Point was the preferred site. ${ }^{52}$

In the middle of April, with ice off the lake, Owen sent Master John Harris and Quarter Master John Aldersley to survey both places for the purpose of choosing one for the naval establishment. Lt.-Gen. George Murray sent a member of the

49 Muster Table for the Lake Champlain Establishment, 12 September 1814 to 30 June 1815, NAUK, ADM 37/5001.

50 Owen to Drummond, 16 June 1815, LAC, RG 8, v. 735, mfr. C2344, 8-17.

51 Prevost to Drummond, 11 June 1814, LAC, Military Secretary Letter Book, Fraser [MSLB-Fr], RG 8, v. 1222, mfr. C3527, 134a.

52 Drummond to Prevost, 14 February 1815, LAC, RG 8, v. 687, mfr. C3231, 108-13. 
Royal Engineers along to assist in the project. ${ }^{53}$ The report on the Grand River site noted the sand bar and the lack of a good anchorage outside the bar. A suggestion was made to build parallel moles through the sand bar to make access to the river easier. Turkey Point had a good anchorage but to secure a dockyard a mammoth building project to raise an area covering eight acres would be necessary. ${ }^{54}$ Owen and Drummond agreed that while the Turkey Point and Long Point area seemed best, the idea was simply too costly, given the "infant state of the Upper Province." At the time of this exchange, Sir Edward was touring Lake Erie at the end of which it seems fairly clear that he favoured the Grand River site, though no final decision was made before he left the station..$^{55}$

As well as ship assignment and crew size, Owen revamped an aspect of the bureaucratic structure.$^{56} \mathrm{He}$ appoint one person on each lake to act as both Agent Victualler and Agent for the Hospital. They would order provisions for all the vessels at one time, preventing the current situation of each vessel making separate requests to the commissioner of the dockyard. He also suggested creating a depot for supplies at York, or Burlington. To store the ordnance from the ships laid up at Kingston, a proper storehouse would be required. As the navy did not have one he would request it from the military. One of the gunners would be assigned to oversee the storage facility. He also arranged with the commissioner that three months worth of supplies would be kept at Kingston and Isle aux Noix. He had yet to select a spot for a depot on the upper lakes.

Drummond approved of almost everything that Owen proposed for the peace establishment.$^{57} \mathrm{He}$ felt that a depot at either York, or Burlington, would be subject to American attack and therefore not a good idea. Sir Gordon sanctioned the use of a military storehouse, at Kingston, for accumulating the navy's ordnance. During July, Sir Edward ordered construction of store houses in the Kingston dock yard to protect naval stores and building material for the ships left unfinished. A stone warehouse was in the planning stage, but Owen knew it would be some time before it was completed.$^{58} \mathrm{He}$ then told the acting dock yard commissioner, Edward Laws,

53 Foster to Murray, 18 April 1815, LAC, MSLB-Fo, RG 8, v. 1234, mfr. C3528, 10.

54 Owen to Drummond, 16 June 1815, LAC, RG 8, v. 389, mfr. C2936, 111-3; Owen to Drummond, 15 August 1815, LAC, RG 8, v. 370, mfr. C2932, 59-60a; \& Drummond to Owen, 24 August 1815, LAC, MSLB-Fr, v. 1228, mfr. C3527, 305-7.

55 Croker to Goulburn, 6 September 1816, Q 138, State Papers Lower Canada, Governor Sir G. Drummond, mfr. C11922. In September 1816, the Admiralty sent its opinion on the choice of the Lake Erie Naval Establishment. It too favoured the Grand River. Deepening the river and building a mole to protect the ships in Mohawk Bay, was left to the Chief Engineer to carry out. Money restraints would cancel the operation.

56 Owen to Drummond, 16 June 1815, LAC, RG 8, v. 735, mfr. C2344, 8-17.

57 Drummond to Owen, 27 June 1815, LAC, MSLB-Fo, RG 8, v.1228, mfr. C3527, 160-1.

58 Owen to Laws, 18 July 1815. QAB1. The stone warehouse, now known as the Stone Frigate, was built during the 1820s, while Captain Sir Robert Barrie commanded the dockyard, 1819 to 1834. See T. L. Brock, "H.M. Dock Yard, Kingston under Commissioner Robert Barrie, 1819-1834." Historic Kingston, 16 (1968), 3-22. Owens to Laws, 19 July 1815, QAB1; Owens to Laws, 12 October 1815, LAC, ADM 1/2264, mfr. B2635, 88-92. 
to amass the lumber necessary to plank the ships on the stocks, to repair ships in service, and to house over those chosen to be laid up.

In Lake Huron HMS Surprise was busy shipping the 1814-1815 presents for the Indigenous tribes of the north west, who were with the British at Mackinac. ${ }^{59}$ As the handover of that fortification to the Americans drew near there was a palpable tension rising among the aboriginal people. The gifts were rushed forward with hopes of calming them before open unrest broke out. But Lt.-Col. Robert McDouall, in charge of the British forces at Mackinac, was upset with the navy for supplying only one vessel for that task, and transporting his troops to the site of the new post, to be built on Drummond Island at the head of Lake Huron.$^{60}$ Owen defended his choice for having Surprise serve the military, while HMS Confiance was employed conducting survey work in Lake Erie. He reassured Drummond that no time would be lost in serving both needs on Lake Huron by Captain Edward Collier and HMS Surprise.

In March, the Admiralty had decided that with peace, the command structure of the naval establishment on the Great Lakes would be reduced. During the war a commissioner of the dockyard tended to issues of the building and supplying of the ships, while a commodore was in command of the ships. This arrangement was not required any longer, so the commodore would come home and the commissioner would assume the control over both the yard and the ships. Commissioner Sir Robert Hall, a captain in the Royal Navy, had filled that position since October 1814. With news of this shift he requested to go back to England and consult with the Admiralty. He departed in late July, which left Commodore Owen in charge until he returned..$^{61}$ The plan was for Hall to return before winter, though he would not return until late in 1816.

Sir Charles Bagot, British Envoy in Washington, wrote to Sir Edward in mid August to inform him of preliminary discussions with the Americans about limitations on the number of ships of war allowed on the lakes. ${ }^{62}$ The reduction would not only be economical, but could "diminish the chances of collisions" between the two countries. The American envoy, John Adams had brought the possibility up in London, after the Treaty of Ghent had been settled. While the British government was uneasy about the idea, the conversation was extended. For now, Bagot was asking Owen to not build any new ships, but he could finish those close to launch; the Americans had the same restriction. ${ }^{63}$ Bagot alluded to

59 Foster to Owen, 14 June 1815, LAC, MSLB-Fo, RG 8, v.1228, mfr. C3527, 129: Foster to Johnson, 19 June 1815, LAC, MSLB-Fo, RG 8, v.1228, mfr. C3527, 141.

60 Drummond to Owen, 4 July 1815, LAC, MSLB-Fo, RG 8, v.1228, mfr. C3527, 178; Owen to Drummond, 10 July 1815, LAC, BMNR, RG 8, v. 735, mfr. C3244, 55-7.

61 Owen to Drummond, 11 July 1815, LAC, BMNR, RG 8, v.735, mfr. C3244, 58-60.

62 Bagot to Owen, 15 August 1815, LAC, BMNR, RG 8, v. 674, mfr. C3171, 105-10. The RushBagot Treaty, which set limits on armaments on the Great Lakes, was ratified in April 1818.

63 In May, James Monroe, secretary of state, had raised the idea with Bagot, after his arrival in Washington, as British minister to the United States. See J S Krysiek. "The diplomatic career of Sir Charles Bagot, The early years: London, Paris, Washington, St. Petersburg (1807-1824)" ( PhD 
a "greatly inferior" American force on the lakes, which was an opinion shared neither by Owen nor Drummond. Since no new building projects were under consideration conforming to Bagot's instructions was easy.

With President Madison's February order the American naval presence on the lakes had radically decreased. Their artificers, needed to complete the great ships on the stocks, had been sent to the east coast yards. The rest of the squadrons on the lakes were largely laid up, those remaining, reduced in armament. A number of the armed vessel that were former merchantmen were sold. ${ }^{64}$ The British had transformed several of their larger vessels into transports. In terms of armament, Owen's downsizing of the British Great Lakes establishment left three gunboats (with a total of ten guns) at Isle aux Noix for Lake Champlain, the Montreal (six guns), and Star (four guns) on Lake Ontario, the Sauk and Huron (with one 18 pounder each) on Lake Erie, and the Surprise and Confiance (with one 18 pounder each) on Lake Huron, though the latter vessel was used in the survey work on Lake Erie and Lake Huron during 1815. The armed sloop HMS Champlain, proposed for Lake Champlain, was launched as a transport vessel. ${ }^{65}$ While this did not match the ultimate Rush-Bagot Agreement figures (one ship of hundred tons, or less, on Lake Champlain and another on Lake Ontario, and two on the upper lakes, each of the four allowed one 18 pounder gun) it was very much the same idea, of a significant reduction in the establishments to save money, and prevent a provocative encounter of heavily armed ships on the lakes. ${ }^{66}$ The three angry encounters that did occur in 1815 , were restricted to the use of muskets and a single cannon, with no injury but that of pride. The only building projects, on both sides, were for transports, and efforts to maintain the ships in ordinary, at a basic level.

\section{Manning of the ships on the Great Lakes}

One of the issues confronting Owen throughout his time on the Lakes was that of manning. At the end of December 1814 there were more than 1,500 officers and seamen, and approximately 400 marines serving on Lake Ontario, an unknown number (but likely very small) serving on the upper lakes, and 232 seamen and 125 marines at Isle aux Noix. ${ }^{67}$ The call from England to send home the majority of the sailors that had served on the lakes during the late war, came quickly.

thesis Marquette University Graduate School, Milwaukee, WI, 1988), 53-4. Later in the dissertation Krysiek states the discussion of the reduction of war ships on the lakes began after 2 May 1816, 121. The present paper indicates it began at the conclusion of the war. Hitsman, has the first suggestion of the disarmament being 15 November 1815, see Safeguarding Canada, 113.

64 Robert Malcomson. Warships of the Great Lakes 1754-1834, (London, UK: Chatham Publishing, 2001), 134.

65 Ibid., 136.

66 See, Burt, 388-394; Bourne, 13-14, 17-18. The agreement was worked out largely by Charles Bagot and James Monroe (then secretary of state), in 1816. It was accepted after Monroe became president, so was signed by Richard Rush, as secretary of the state, 29 April 1817.

67 Flotilla Lake Champlain Muster Table, 15 September 1814 to 30 June 1815, NAUK, ADM $37 / 5001$. 
As long as Owen needed the ships on Lake Ontario to move troops out of the province he needed the squadron with the majority of the seamen. One of the first groups he removed from the ships were volunteers from the Provincial Marines. ${ }^{6}$ After reviewing the list of seventy provincial men serving in the squadron he released them immediately. In June, the Psyche was put into ordinary, and Captain Peter Fisher, along with just over 350 sailors, left for Quebec. ${ }^{69}$

With the 250 Royal Marines sent to Cornwall, and others straight home, by July, Owen did not have enough to post sentries in as many places around the dockyard as had been routine. ${ }^{70}$ Major General Sir Frederick Robinson complained that there would only be enough marines to guard the outer gate of the dockyard. He reminded Owen that it was his responsibility to provide security for the entire dockyard. Sir Edward's response is unknown.

At the same time the Admiralty wrote the commodore again, telling him to send home the seamen from the lakes and replace them with volunteers. ${ }^{71}$ To this end he wrote Drummond about opening a rendezvous to collect volunteers at Montreal and Quebec. Owen would make an effort at Kingston to elicit volunteers from among the upper province's population. In August, Lieutenants George Hugo and William Venus were sent from Kingston to Quebec and Montreal, respectively, to command the rendezvous. ${ }^{72}$ Drummond thought the idea of using "Canadian Inhabitants" for naval service was a good one, "yet I feel apprehensive, that but few will be induced to engage on any terms, a Change from their present unrestrained life of Idleness and high wages for the little labor they do perform to a state of Comparative restraint, not being suited to their disposition." 73

The rendezvous for volunteers was a mixed success. The Montreal post did not gather very much interest, and the expenses were more than the budget he had set aside. In November, Owen recalled Lt. Venus, placing him as a supernumerary in Prince Regent, ordering him home in the spring. ${ }^{74}$ Venus brought the eleven men he recruited with him to Kingston. Lt. Hugo had been far more successful at Quebec, raising fifty-six men, "an excellent class of men" which Owen felt had a positive effect on those serving on the lakes. He asked Croker to keep the Quebec rendezvous open through the winter, to attract men from transports staying there until spring. ${ }^{75}$

68 Owen to Drummond, 28 April 1815, LAC, RG 8, v. 734, mfr. C3244,98-101.

69 Drummond to Bathurst, 1 July 1815, LAC, MSLB-Fo, RG 8, v. 1230, mfr. C3528, 39-40.

70 Robinson to Owen, 10 July 1815, LAC, Frederick Robinson Letter Book [FRLB], RG 8, v. 1325, mfr. C3548, 63-4.

71 Owen to Drummond, 11 July 1815, LAC, RG 8, v. 735, mfr. C3244, 63-4.

72 Owen to Drummond, 5 August 1815, LAC, RG 8, v.735, mfr. C3244, 101-4. Hugo had come out to the lakes as a midshipman with Yeo, and served throughout the war being appointed by him as acting lieutenant of HMS Charwell. See O'Byrne, 552-553. Venus was sent out to the lakes in 1814. See O’Byrne, 1228.

73 Drummond to Owen, 18 July 1815, LAC, MSLB-Fo, RG 8, v. 1228, mfr. C3527, 216.

74 E. Owen to W. Owen, 18 November 1815, LAC, Colonial Office Original Correspondence Secretary of State, [CO], v. 42/171, mfr. B137, 252-52b.

75 E. Owen to W. Owen, 18 November 1815, LAC, CO, v. 42/171, mfr. B137, 253-53b. 
Owen proposed to the Admiralty that a rotation system be established concerning service on the inland seas.$^{76}$ Three year terms would be set, with the first two spent on the upper lakes and the third on Lake Ontario, or at Isle aux Noix. The upper lakes would discourage desertion and make the service on the lower lake a reward. He suggested rotating thirty men through the system, before winter every year. For those volunteering through the Quebec rendezvous and set to leave at the end of three years, being at Kingston or Isle aux Noix, would make it easier to send them back to Quebec for the trip home, in the spring. He told Croker that the province would never supply enough men, and that volunteers from England would always be needed. Land grants were a good idea for those coming out to serve, but he cautioned not to give too many and cheapen the reward. Grants should only be given to seamen who had served three to six years in His Majesty's Service, and three years on the lakes.

With the laying up of the Niagara, in October, another sixty-two men were sent to England. ${ }^{77}$ In March, the Niagara had contributed twenty-six seamen to HMS Confiance, on Lake Erie. In October, while those who went home left, eightythree of the crew were sent to other ships in the squadron, twenty-six alone were sent into HMS Star. Niagara was followed into ordinary by Prince Regent. The Montreal, Star and Netley, were laid up for the winter. This released more men from their ships. Many of those from Prince Regent were sent into the Princess Charlotte, which had been severely undermanned, throughout 1815 .

Desertion was a drain on manpower after the war, for both the navy and the army. When the troopship Penelope wrecked near Quebec the surviving crew became insubordinate and many deserted.$^{78}$ Owen felt that it set a bad example to men serving on the station, to see the deserters get away, so he asked Drummond to set a reward for their capture. Drummond declined but did assign the police and Quebec magistrate to apprehend them. He told Owen that the navy ought to post the reward, but none was.

With the return of 400 seamen and officers from captivity in the United States, in May, Owen stated that, "the disposition to desert existed in a great degree at Kingston." 79 While Sir Edward was in Quebec, during part of May, more than one hhundred seamen deserted at Kingston. His only solace was that the army had just as big a problem with men running. HMS Niagara, whose full muster exists for the first ten months of 1815 , lost fourteen men from its complement of 163 ,

76 Owen to Croker, 2 December 1815, LAC, CO, v. 42/171, mfr. B137, 250-51. E. Owen to W. Owen, 18 November 1815, LAC, CO, v. 42/171, mfr. B137, 253-53b.

77 Muster Table HMS Niagara, 1815, NAUK, ADM 37/5377. The only other two tables that indicate men going home in 1815 are for HMS St Lawrence Muster Table, Oct 1814 to March 1815. NAUK, ADM 37/5074, which sent fourteen before June, and HMS Princess Charlotte Muster Table, 1815. NAUK, ADM 37/55245, which sent home forty-eight men between June and August.

78 Owen to Drummond, 24 May 1815, LAC, RG 8, v. 734, mfr. C3244, 133; Foster to Owen, 27 May 1815, LAC, MSLB-Fo, RG 8, v. 1228, mfr. C3527, 113; Owen to Foster, 12 June 1815, LAC, RG 8, v. 735, mfr. C3244, 21-2.

79 Owen to Croker, 26 May 1815, LAC, ADM 1/2263, mfr. B2635, 119-25b. 
between March and July, with a dozen running in the later month. One man ran at York, six when the ship was at Niagara, on 7 July, and seven when it returned to Kingston in late July. ${ }^{80}$ Desertion was not just a Lake Ontario phenomenon. Men were deserting from the ships involved in the survey of Lake Erie, in one case causing a significant international incident. ${ }^{81}$

The British base at Isle aux Noix saw its share of desertion, as well. The muster for the first six months of 1815 reveals fifty-three seamen and seven marines running from the King's service. ${ }^{82}$ March 1815 was the worse month for seamen fleeing, with forty departing over six separate dates. On the 12 th, nineteen men ran and three nights later another nineteen departed from the barracks, at Isle aux Noix. During the year 23.7 per cent of the Royal Navy seamen eloped. Among the Royal Marines the percentage was only 5.3 per cent, but the fact that, overall, marines tended not to desert, makes this, if not significant, certainly note worthy ${ }^{83}$ Repairs were made to the naval barracks in June, from which many of the deserters had fled at the end of the winter. ${ }^{84}$

Some Americans were apparently inciting desertion from both services. In at least one case, an American sergeant was seducing British soldiers to desert, with promises of opportunity and freedom. ${ }^{85}$ Drummond wrote Anthony St John Baker, British chargé d'affaires in Washington, asking him to deliver a formal protest about the desertion to the American government. ${ }^{86}$ Secretary of State John Monroe replied that he would discourage further incitements, but the problem continued ${ }^{87}$ It appears that seamen and troops of His Majesty's forces in the upper province were competing to see who could desert the most. Sir Frederick Robinson wrote Drummond in September that "with our present infected set, neither the Navy or

80 Muster Table HMS Niagara, 1815, ADM 37/5377. The deserters included two landsmen, one ordinary and five able body seamen, plus one each of, a gunner's mate, boatswain's mate, quarter gunner, captain of the top, and a quarter master's mate. Only one man had been demoted three were promoted while in the ship.

81 Owen to Drummond, 2 October 1815, LAC, RG 8, v. 736, mfr. C3244, 6-7. Lt. Alexander Vidal went in pursuit of the deserters and the personal property they had stolen. He was arrested and tried in Detroit, causing the international incident. He was released after paying a fine, two months after his arrest.

82 Muster Table for Lake Champlain, Isle aux Noix, 15 September 1814 through 30 June 1815, NAUK, ADM 37/5001. The rating of the men reflects that in the muster table, only five were able body seamen, while twenty-eight were ordinary seamen, twenty-five were landsmen, and one was from the carpenter's crew. There were 225 officers and seamen and 133 Royal Marine officers, NCOs and privates in the muster table during the time period.

83 During this period marines were less likely to run than seamen. See, Thomas Malcomson, Order and Disorder in the British Navy, 1793-1815 (Woodbridge, UK: Boydell Press, 2016), 125; T. Malcomson. "Muster Table for the Royal Navy's Establishment on Lake Ontario during the War of 1812" The Northern Mariner/Le marin du nord 9:2 (April/Avril 1999), 41-67.

84 Foster to Owen, 23 June 1815, LAC, MSLB-Fo, RG 8, v. 1228, mfr. C3527, 146.

85 Drummond to Baker, 17 June 1815, LAC, Drummond to Baker Letter Book [DBLB], RG 8, v. 1236, mfr. C3529, 13-4. See Burt, 378-379.

86 Drummond to Baker, 10 August 1815, LAC, DBLB, RG 8, v. 1236, mfr. C3529, 23-4.

87 Burt, 387. 
Army can place confidence in any one under the rank of a commissioned officer." ${ }^{8}$

\section{October 1815, final arrangements on the lakes and departure for home}

In October, Owen had Edward Laws, acting dockyard commissioner, begin necessary repairs to St Lawrence and Princess Charlotte. ${ }^{89}$ Without the proper careening gear at Kingston to repair Prince Regent's damaged keel, Sir Edward ordered the ship to be housed over. The Montreal, Star, and Netley were also to be housed over, as they were taken out of service. The defects of the these ships, now in ordinary, were to be tended to. The Niagara was considered not worth housing over, but its masts and spars were removed, and the hatchways closed up to prevent rain and snow from entering the vessel. Any extra lumber was to be stored under sheds. Masts and spars would reside in the mast pond, next to the dock yard. Owen then issued orders to maintain the ships in ordinary. These included airing them twice a week and pumping when necessary, to keep them dry, not allowing anyone to stay aboard, lighting heaters twice a week to dry the ship, attended by a warrant officer and to be inspected every evening by the warrant officers.

Owen decided in October to house over the two ships on the stocks. ${ }^{90}$ Laws was told to change the position of the chokes (sic - chocks) on ship 1, as they had been improperly placed. Then the workers were to take "out the filling pieces between the Timbers and (pay) them with Tar" and then caulk both sides, of both vessels on the stocks. He could hire sawyers to get the work done, if necessary. But the sense of caution over the expense was underlined as Law was told to auction off the extra oxen and horses, no longer needed in the dock yard.

For Sir Edward, Penetanguishene was not shaping up to be an acceptable location. ${ }^{91}$ It would take two winters and a summer to get heavy guns from York to the proposed site, far too slow. With no suitable trees for ship building and impassible roads for most of the year, and no prospect of better roads soon, Owen suggested dropping any immediate further development. Instead he focused on the new post, in northern Lake Huron, that the British would shift to after they returned Mackinac to the Americans.

Commodore Owen appointed Lieutenant Hambly acting captain and commander of the Lake Huron Establishment. Hambly was ordered to collect his vessels at the mouth of the Nottawasaga River for the winter. ${ }^{92}$ The store houses at Kempenfelt Bay and Holland River were under his direction and were to be placed under the

88 Robinson to Drummond, 26 September 1815, LAC, RG 8, v. 167, mfr. C2774, 183-5.

89 Owen to Laws, 6 October 1815, LAC, ADM 1/2264, mfr. B2635, pp 87-7b; \& Owen to Laws, 12 October 1815, LAC, ADM 1/2264, mfr. B2635, 88-91b.

90 Estimate of the Expense of Workmanship and Material for Building two sheds to cover the new Ships, No. 1 \& 2 on the Stocks. William Bell, 3 October 1815, LAC, ADM 1/2264, mfr. B2635, 85; Owen to Laws, 16 October 1815, QAB1; \& Owen to Laws, 23 October 1815, QAB1.

91 Owen to Drummond, 14 April 1815, LAC, RG 8, v. 370, mfr. C2932, 11-17.

92 Instructions No. 2 for the Commander of the Naval Establishment upon Lake Huron, 12 October 1814, LAC, RG 8, v. 736, mfr. C3244, 30-1. 
purser and given an appropriate guard. He could erect huts for the officers and men and a store house for supplies at the mouth of the Nottawasaga, but they were to be of a temporary nature and inexpensive. The vessels for Lake Huron were to be repaired and readied for the spring. Hambly could build boats and bateau, as needed. He was to examine the coast west of Nottawasaga, for a potential site for a naval yard to allow ship building. His progress on this issue was to be reported to the senior officer. In spring he was to carry supplies to the new post on Drummond Island and cooperate with the commanding officer. His officers were to make note of navigational aspects of the lake, including sketches and surveys when convenient. All such information was to be forwarded to the senior officer on the lakes. Hambly was to sail with the various vessels under his command and explore the lake. When not otherwise occupied his vessels were to prevent inappropriate trade, in conjunction with the officer in charge of the Collection of Customs. The name of any ship spoken to was to be recorded and this too passed to the senior officer of the lakes.

As the 1815 sailing season drew to a close, the British had three vessels active on Lake Ontario; Montreal, Star, and Netley served as transports..$^{93}$ St Lawrence was a floating barracks, while Prince Regent, Princess Charlotte, Psyche and Niagara were in ordinary. Besides these vessels the British had the frames of two first rate ships on the stocks at Kingston. HM Transport Champlain rested at anchor at Isle aux Noix. The schooners Saulk, Huron, Tecumseth and Newash were on Lake Erie, the latter two as transports. Surprise and Confiance were on Lake Huron. This was the establishment that Owen left behind on the lakes, and which he saw as sufficient for the immediate needs. Those ships in ordinary, or serving as unarmed transports, could, with relative ease, be returned to fighting form if hostilities broke out. Of course, the Americans had their larger ships in ordinary, and on Lake Ontario two 118 gun ships on the stocks. The United States had a superior supply line to the lakes, one that would only get better in the decades ahead. This made it likely that the next war would see the Americans ultimately capable of out-building the British and seizing control of the lakes. This assumed the United States would not immediately cut the upper province's life line: the St Lawrence River. In that scenario the British squadrons on the lakes would either be kindling, or American, in short order.

As October began and Sir Edward Owen prepared to return to England, one more major project that received his attention was the building of a steamboat to ply the St Lawrence River from the last rapids to Kingston. ${ }^{94}$ He wrote to Croker encouraging the undertaking, suggesting that it be run by private individuals with government oversight. There was a group ready to invest, if the machinery could

93 List of Officers Serving on Broad His Majesty's Ships and Vessels on the Lakes of Canada..., 15 October 1815, LAC, ADM 1/2264, mfr. B2635, 129-b; \& Owen to Drummond, 15 October 1815, LAC, RG 8, v. 736, mfr. C3244, 21-2.

94 Owen to Croker, 28 October 1815, LAC, CO 42/171, 76-8. 
be obtained.$^{95}$ The Admiralty could send it out, Sir Edward suggested. It would be of infinite service in transporting stores into the lakes. Since the Americans were in the process of building a steamboat for river service it seemed imperative that the British have one as well.

In one last act as commodore, Owen sent a private and confidential letter to the captains and commanders serving on the Lakes. ${ }^{96}$ In it he noted the various acts of aggression by American civil authorities against British officers and seamen, and the acrimonious press. This kept the animosity of war alive, he wrote, and cautioned them to be careful and vigilant against such invective and antagonism. Owen predicted that if the Americans went to war again, they would be defeated by the British on the lakes.

On the eve of his departure Sir Edward Owen turned the dockyard administration over to Edward Laws ${ }^{97} \mathrm{He}$ then wrote his brother William, sending him the official correspondence to read, and then pass on to Sir Robert Hall when he returned..$^{98} \mathrm{He}$ praised his brother's survey work and the detailed reports he had sent along. Sir Edward then laid out a fifteen point set of instructions for William. ${ }^{99} \mathrm{He}$ charged William with completing the survey of the St Lawrence River, Lakes Ontario, Erie, Huron and Georgian Bay. During the winter they were to survey as much of the shoreline as possible. Special attention was to be paid to Kingston harbour and the surrounding area, as well as the islands in the Niagara River above the falls, the mouth of the Grand River and Drummond Island in Lake Huron. William was ordered to send his detailed reports directly to the Admiralty.

On 5 November Sir Edward turned command of the Great Lakes over to his brother William. He then departed Kingston for Quebec, stopping at Montreal to talk with James Walker, about arranging for a new naval storehouse, at St Helens. ${ }^{100}$ Reaching Quebec on 18 November, he met with Sir Gordon Drummond several times before leaving for England. ${ }^{101} \mathrm{He}$ then wrote one last set of instructions for William Owen, back in Kingston. ${ }^{102} \mathrm{He}$ cautioned William to keep a close eye on the officers in the hospital, "whose Conduct I have found it needful to reprove for inattention." The artillery stores in the naval yard were to be removed. The Charwell, acting as a magazine, ought to be re-converted to a transport. $\mathrm{He}$ ordered William to build a vessel for the use of the lieutenant-governor of the upper province. Sir Edward asked William to examine the various routes to the Grand River, from Forty Mile Creek and Burlington, to decide which was best. All decisions concerning Penetanguishene were to be directed to the Admiralty, but improvements were to be made along the Nottawasaga route to Lake Huron. On

95 “Steam Boat," Kingston Gazette 5.25 (25 November 1815), 3.

96 Owen to Captains and Commanders, 5 November 1815, LAC, CO 42/171, 278-9.

97 Owen to Laws, 28 October 1815. QAB1.

98 E. Owen to W. Owen, 2 November 1815, LAC, CO 42/171, 284-5b.

99 E. Owen to W. Owen, 5 November 1815, LAC, CO 42/171, 256-61b.

100 Owen to Drummond, 17 November 1815. LAC, RG 8, v. 736, mfr. C3244, 69-72.

101 Owen to Drummond, 19 November 1815, LAC, RG 8, v. 736, mfr. C3244, pp 80-1.

102 E. Owen to W. Owen, 19 November 1815, LAC, RG 8, v. 736, mfr. C3244, 82-6. 
24 November 1815, Sir Edward Owen boarded the merchant ship Juliana, the last vessel to leave Quebec for the season, and headed home.

He left Canada with the praise of Major-General Louis de Watteville, commander of the British forces in Upper Canada. and the governor in chief, Sir Gordon Drummond. De Watteville expressed his thanks for the navy's untiring efforts for the good of the province, and its willingness to cooperate with the army. ${ }^{103}$ Drummond noted his high regard for Sir Edward in a letter to Lord Bathurst, stating, "Sir Edward Owen's professional character most deservedly stands in the foremost rank of British naval Officers. But his judgement and experience, his systematic arrangement, his combating yet decisive manner and his anxious wish to offer every assistance in his power to the wants and convenience of the Army... render him peculiarly well adapted for the supreme control of His Majesty's Naval Service in the Canada." ${ }^{104}$ He closed the letter with the request that if war book out again, Sir Edward Owen would be returned to service on the Lakes.

\section{Discussion and Conclusions}

Sir Edward Owen's time on the Great Lakes was short but productive. He was sent to do battle with the Americans and win control of those lakes, or at the very least keep the Americans from gaining it. With peace, his mission changed as the task became one of reducing the number of ships-of-war and men serving on the lakes. Though the Treaty of Ghent had stopped the fighting, animosity still churned among the Americans along the Great Lakes frontier. Owen shifted the naval war footing to a peace establishment that could quickly re-mobilize if the flames of war reignited.

Scaling back the building activity, and making sure the ships of the squadron were in the best shape possible was a big task. It is apparent form the correspondence covered in this paper that the British ships on Lake Ontario were not in the best condition. At some point the Prince Regent, Psyche, Niagara, Montreal and Charwell were all subject to needed repairs limiting their service. Owen found the brigs and smaller vessels of the British were no match for the same class of American vessels. If war had continued and this squadron met the American's, control of the lake, and thus the fate of the upper province, may have gone to the Untied States. Even as he reduced the squadron on Lake Ontario, Sir Edward had to firm up the British presence on the upper lakes. At the same time economy and the related downsizing of the overall establishment complement made the assignment all the more difficult.

Both America and Britain wanted the peace that the Treaty of Ghent had procured to survive and reducing the danger of an incendiary incident on the lakes was a major step toward that end. Yet at the same time the British had to maintain a

103 de Watteville to Owen, 31 October 1815, LAC, FRLB, RG 8, v. 1325, mfr. C3458, 43.

104 Drummond to Bathurst, 19 November 1815, LAC, MSLB-Fo, RG 8, v. 1230, mfr. C3528, 64-5. 
force that could be brought back to a war footing quickly if peace failed. The Americans had the advantage of the lakes resting on their industrializing nation's northern shoreline. For the British, the colonies were far from self-sufficient, and a navy on the inland seas would require assistance from Britain, across the Atlantic Ocean. All the problems of transportation that existed during the recent war would still exist in any war in the near future. The Rush-Bagot Agreement that would be signed in 1817 would result, as intended, in markedly reducing both British and American readiness on the lakes. It did not however, create a pacified border, as both nations built forts and canals over the next few decades, that not only defended their territory, but created points at which they could mount offensive operations. In the time between the war and the Rush-Bagot Agreement the British kept a delicate balance between a de-escalation of arms and preparedness on the Great Lakes. In this, Sir Edward William Campbell Rich Owen played an essential role. 